\title{
Zabawy literackie w szkole podstawowej - czytanie, pisanie i interpretacja głosowa
}

\author{
Literary Fun in Primary School. \\ Careful Reading. Careful Writing
}

\author{
|Maciej Wróblewski \\ Uniwersytet Mikołaja Kopernika w Toruniu \\ IORCID: 0000-0002-6386-7168
}

\begin{abstract}
An article is based on the reflections and observations induced by the workshop "Literary Fun. Careful Reading. Careful Writing" ("Zabawy literackie. Piękne czytanie. Piękne pisanie") which was conducted in several primary schools Cuiavia-Pomerania region. The main goal of this project, funded by Ministry of Culture and National Heritage, was to improve different skills among pupils from 12 to 15 aged. First of all, a close reading of the paragraphs of the novels, short stories, and reportages by former and contemporary Polish or foreign writers, for example: M. Rej, H. Sienkiewicz, M. Wańkowicz, J. R. R. Tolkien, S. Mrożek, S. Lem, O. Tokarczuk and R. Kosik. The workshops consisted from the three parts, the first was built on the association activities, the next relates to the oral interpretation, and the last focuses on a creative writing process. The association activities enable to encourage mental activity of the young people. After that the pupils tried to orally interpret the pieces of the literary texts in order to grasp certain melody, rhythm, and meaning. During the last part in a creative writing process young people wrote their own stories which begun from a short cite (one or three sentences) of the literary texts. Unfortunately, the results of this project demonstrate a lack of practical skills among students. First of all, they were not able to read carefully different literary genres, they had troubles with the oral interpretation of the texts and a large majority of the participants of the "Literary Fun" wrote unsophisticated texts and they were secondary to the original and testified the poor vocabulary use of their authors.
\end{abstract}

Key words: creative writing, pupils, primary school, oral interpretation

${ }^{1}$ Zrealizowano w ramach stypendium Ministra Kultury i Dziedzictwa Narodowego

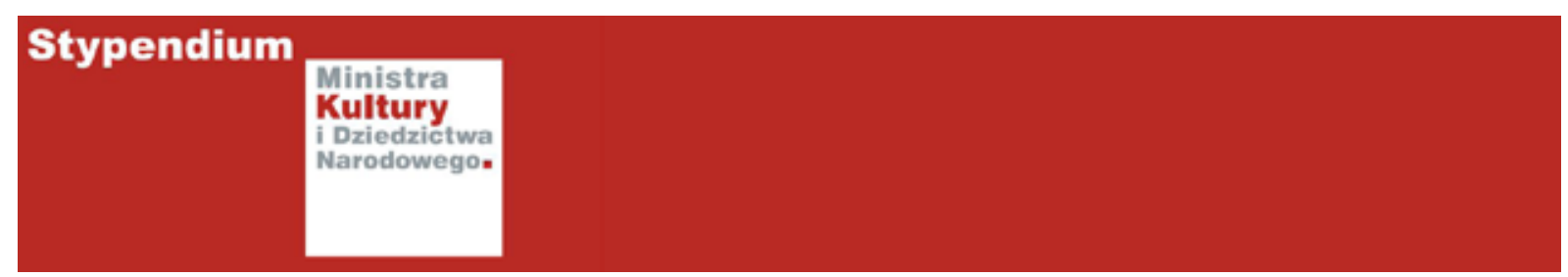


Streszczenie: Zawarte $\mathrm{w}$ artykule refleksje i uwagi, odnoszące się do podstawowych umiejętności uczniów szkół podstawowych województwa kujawsko-pomorskiego, a w szczególności do czytania ze zrozumieniem, interpretacji głosowej oraz pisania są efektem realizacji projektu „Zabawy literackie. Piękne czytanie. Piękne pisanie”, finansowanego przez Ministra Kultury i Dziedzictwa Narodowego. Jego uczestnicy wykonywali ćwiczenia związane z czytaniem, interpretacją głosową i twórczym pisaniem w związku z lekturą wybranych fragmentów powieści, opowiadań czy reportaży polskich i zagranicznych pisarzy dawnych i współczesnych, m.in. M. Reja, H. Sienkiewicza, M. Wańkowicza, J. R. R. Tolkiena, S. Mrożka, S. Lema, O. Tokarczuk i R. Kosika. Warsztaty składały się zazwyczaj z trzech części: ćwiczeń wprowadzających opartych na działaniach skojarzeniowych, uważnego czytania wcześniej przygotowanych fragmentów i interpretacji głosowej tekstów literackich oraz twórczego pisania. Celem pierwszej części było mentalne pobudzenie uczniów do kreatywnej pracy związanej, w dalszej kolejności z doskonaleniem umiejętności uważnego czytania i kreatywnego pisania. Niestety, w wyniku poczynionych obserwacji należy stwierdzić, że większość uczniów czytała teksty literackie powierzchownie i nie potrafiła ustalić, które informacje w nich zawarte są ważne. Również uczniowskie teksty, wywiedzione z jednego bądź kilku zdań czytanego utworu, pod względem fabularnym miały charakter wtórny w stosunku do oryginału i świadczyły o ubogim słownictwie ich autorów.

Słowa kluczowe: twórcze pisanie, uczniowie, szkoła podstawowa, interpretacja głosowa

1.

Nie będzie odkryciem refleksja, że kształcenie na poziomie szkoły podstawowej, szczególnie gdy chodzi o przedmioty główne, jak język ojczysty i obcy, matematyka i informatyka, ale także historia i biologia, jest niezmiernie ważne i determinuje rozwój człowieka w długim okresie. Twórcy i komentatorzy podstawy programowej wyrażają podobne stanowisko. W ministerialnym dokumencie możemy bowiem przeczytać:

Kształcenie w szkole podstawowej stanowi fundament wykształcenia. Zadaniem szkoły jest łagodne wprowadzenie dziecka w świat wiedzy, przygotowanie do wykonywania obowiązków ucznia oraz wdrażanie do samorozwoju. Szkoła zapewnia bezpieczne warunki oraz przyjazną atmosferę do nauki, uwzględniając indywidualne możliwości i potrzeby edukacyjne ucznia. Najważniejszym celem kształcenia w szkole podstawowej jest dbałość o integralny rozwój biologiczny, poznawczy, emocjonalny, społeczny i moralny ucznia (Podstawa programowa b.r.w., 5)

Myśl o znaczeniu edukacji na pierwszym etapie, uderzająca swoją oczywistością, nawiedzała mnie, ilekroć przekraczałem progi szkół podstawowych - wiejskich i miejskich - w województwie kujawsko-pomorskim od stycznia do marca oraz we wrześniu 2020 roku w związku z realizacją projektu „Zabawy literackie. Piękne czytanie. Piękne pisanie”, finansowanego przez Ministra Kultury i Dziedzictwa Narodowego ${ }^{2}$. Pomysł warsztatów, których istotą jest połączenie interpretacji głosowej fragmentu utworu literackiego z doskonaleniem umiejętności pisania, wywiedzionego ze zdań lub zdania przeczytanego głośno utworu literackiego, nie stanowił dla mnie

${ }^{2}$ W projekcie wzięli udział uczniowie ze szkół podstawowych w Brodnicy, Gronowie, Gołuchowie, Lubiczu Dolnym, Wałdowie Szlacheckim, Grudziądzu, Włocławku i w Toruniu. W sumie w warsztatach wzięło udział 223 uczniów w wieku od 12 do 15 lat. Jedna grupa warsztatowa nie przekraczała 15 uczestników. 
nowości. Podobną strategię kształcenia różnych predyspozycji komunikacyjnych (czytanie - mówienie - pisanie) realizuję od wielu lat na kierunku lingwistyka praktyczna i copywriting w ramach ćwiczen „Twórcze pisanie”. Uznaję bowiem, że także na studiach o profilu humanistycznym niezbędne jest pogłębianie praktycznych umiejętności komunikacyjnych i kompetencji językowej. Oczywiście, mam świadomość, że na poziomie szkoły podstawowej proces edukacji w tym zakresie przebiega inaczej, choć cele są zbieżne (Koc 2011, 151-176; Kłakówna 2016, 129-202).

Dzięki przeprowadzeniu warsztatów, w których udział wzięło w sumie ponad dwustu wychowanków z różnych regionów województwa kujawsko-pomorskiego, uczęszczających od klasy szóstej do ósmej, miałem szansę porównać ich wiedzę i umiejętności z wiedzą i umiejętnościami studentów. Pod powierzchnią oczywistych różnic, wynikających i z wieku, i z długości okresu edukacji, ale także życiowego doświadczenia, dostrzegłem kilka podobieństw, które mają charakter zjawiska głębszego, a więc odnoszącego się do sposobu traktowania tekstu literackiego i nieliterackiego. Pierwsze z nich dotyczy nieumiejętności czytania ze zrozumieniem, a dokładniej sprawę ujmując - skłonności większej części uczniów i niemałego odsetka studentów do lektury każdego tekstu w sposób powierzchowny i „wyspowy”, to znaczy bez podjęcia wysiłku ustalenia hierarchii ważności występujących w nim informacji. Konsekwencją tego były problemy z wykonaniem nie tylko złożonych czynności, jak analiza i interpretacja, ale również nieco prostszych, a więc odnoszących się do określenia treściowej zawartości tekstu, którą można sprowadzić do kilku podstawowych pytań, dobrze znanych z tradycji retorycznej (gr. heúresis, łac. inventio): kto? co? gdzie? z pomocą czego? dlaczego? w jaki sposób? kiedy? (Korolko 1998, 58 - 60). Drugie z podobieństw odnosi się do jakości warstwy frazeologicznej tworzonego wypowiedzenia, co może wynikać z niewystarczającej świadomości językowej ucznia i studenta odnoszącej się do warunków, w których przebiega dany akt komunikacyjny.

Celem edukacyjnym nie jest zatem opanowanie jak największej liczby informacji o systemie gramatycznym, ale opanowanie przez ucznia umiejętności samodzielnego tworzenia aktów mowy, ich oceny, rozpoznawania intencji, stosowności, poprawności. Aby zadanie to było wykonalne, należy mieć na uwadze warunki dobrego komunikowania się (Koc 2011, 157).

Do wskazanych podobieństw określonych „niedyspozycji” można dorzucić następne, które dotyczy kompozycji wypowiedzi ustnych i pisanych. O ile spontaniczny akt komunikacji rządzi się swoimi prawami i zazwyczaj trudno jest nadać mu precyzyjną formę, o tyle każdy tekst tworzony w określonych ramach kompozycyjnych (wyznaczanych przez gatunek, konwencję, intencję) wymaga wcześniejszego przygotowania ze strony jego autora (Wróblewski 1998). Uczniowie biorący udział w warsztatach niezwykle rzadko sporządzali konspekt bądź szkic pisemnej wypowiedzi, podobnie 
było w wypadku studentów. Mimo zachęt z mojej strony słuchacze nie tyle nie chcieli przygotować zarysu tekstu, ile nie bardzo wiedzieli, w jaki sposób należy się do tego zabrać. Nie mniej problemów sprawiało im głośne czytanie przygotowanych przeze mnie prozatorskich fragmentów. Z przeprowadzanych z uczniami rozmów wynikało, że ta aktywność rzadko bywa aranżowana przez nauczyciela w czasie lekcji, choć - jak się okazywało w trakcie różnych ćwiczeń - dopiero głośne odczytanie, a potem interpretacja krótszych bądź dłuższych fragmentów pozwalała większości z nich zrozumieć treść utworu ${ }^{3}$. To z kolei otwierało drogę do bardziej zaawansowanych czynności, które można określić mianem analizy.

Zanim przedstawię bardziej szczegółowe informacje dotyczące przebiegu warsztatów, zamknę część wstępną rozważań jeszcze jedną refleksją, tym razem odnoszącą się do motywacji i zaangażowania uczniów biorących udział w projekcie. Miał on charakter przedsięwzięcia zarówno pragmatycznego, jak i popularyzatorskiego. Uznałem bowiem, że kształcenie polonistyczne w (nowej) szkole podstawowej wciąż jeszcze znajduje się na etapie przebudowy i reorganizacji. Aby przejść na kolejny etap, powiedzmy „dojrzałości”, niezbędna jest kumulacja doświadczenia nauczycieli jednego bądź kilku pokoleń, by można było rozwiązywać codzienne problemy w możliwie pewny sposób, wykorzystując w tym celu wiedzę i umiejętności innych. Na przykład, moja pamięć o szkole podstawowej sprzed reformy Ryszarda Handkego, a więc sięgająca ponad 20 lat wstecz, w niewielkim stopniu pozwala mi wykorzystywać własne doświadczenie nauczyciela prowadzącego lekcje polskiego w klasach 4 - 8. Nie tylko zmienili się uczniowie i warunki pracy (nowe media, cyberprzestrzeń), ale także sposób traktowania literatury i - ogólnie rzecz ujmując - tekstu, co w konsekwencji determinuje drogę wychowanka do zdobycia niezbędnej wiedzy i koniecznych do skończenia szkoły podstawowej umiejętności. Tu najważniejszym punktem odniesienia jest test ósmoklasisty, a niekoniecznie konsekwentna realizacja treści programowych w sposób, który wedle wiedzy poszczególnych pedagogów byłby optymalny dla ich wychowanków oraz wspierał proces budowania autonomii zarówno nauczyciela, jak i ucznia (Myrdzik 2020, 7-19). A zatem rozwijanie, na przykład, pasji czytelniczych, umiejętności interpretacji głosowej czy tworzenia różnych form wypowiedzi pisemnych zazwyczaj zwrócone jest w kierunku tego, co zostało zaprogramowane w kończącym szkołę podstawową egzaminie. $\mathrm{W}$ tym sensie potraktowałem realizację projektu jako działanie pragmatyczne. Poniekąd uznałem to za konieczność choćby dlatego, że po rozmowie z władzami kuratoryjnymi w Toruniu okazało się, że uczniowie kujawsko-pomorskich szkół nie najlepiej wypadli w teście ósmoklasisty w roku 2019, szczególnie gdy chodzi o język polski.

${ }^{3} \mathrm{~W}$ ministerialnym dokumenciew punkcie odnoszącym się do umiejętności mówienia i pisania w klasach IV - VI znajduje się następujący zapis: „Uczeń (...) wygłasza z pamięci tekst, ze zrozumieniem oraz odpowiednią intonacją, dykcją, właściwym akcentowaniem, z odpowiednim napięciem emocjonalnym i z następstwem pauz" (Podstawa programowa, 15). 
Wraz z realizacją określonych celów pragmatycznych starałem się popularyzować czytanie jako formę spędzania wolnego czasu. Robiłem to z nadzieję, że przynajmniej część uczestników warsztatów przekona się do tego, że immersja literacka jest także przyjemna, a przy tym wartościowa. Według najnowszych badań dramatycznie niskie wskaźniki przedstawiające stan czytelnictwa w Polsce przestały w roku 2019 spadać. Ponadto właśnie grupa wiekowa szkolna czyta najwięcej i zapewne nie tylko dlatego, że uczniowie muszą to robić ze względu na edukacyjne obowiązki, ale część z nich sięga po książkę dla własnej satysfakcji.

Jak wynika z raportu Biblioteki Narodowej, w 2019 roku można odnotować trwałe zatrzymanie spadku czytelnictwa, a nawet niewielki wzrost deklaracji czytelniczych. Jest to w pewnej mierze wynik dobrej koniunktury, która pozwoliła na wzmożone zakupy nowości książkowych, ale również podsycania zainteresowań czytelniczych przez ekranizacje, seriale czy gry komputerowe. Niewątpliwie znaczącą rolę w kształtowaniu gustów czytelniczych mają prestiżowe nagrody literackie, jak Nagroda Nobla dla Olgi Tokarczuk (Stan czytelnictwa w Polsce 2020).

Starałem się zatem tak aranżować warsztaty, by młodzi ludzie dostrzegli w literaturze nie tylko mniej lub bardziej obcą im dziedzinę sztuki, ale przede wszystkim efekt racjonalnej pracy człowieka odsłaniającej jego sposób patrzenia na rzeczywistość. W związku z tym czytanie konkretnego utworu w ramach ministerialnego projektu traktowałem również jako możliwość poznania ludzkich doświadczeń komunikowanych za pośrednictwem określonej konwencji czy gatunku. Podkreślałem jednak na każdym spotkaniu fakt, że literatura - czy to fikcjonalna, czy dokumentalna - jest przede wszystkim formą ekspresji, rodzajem autoportretu tego lub innego pisarza. Nawet jeśli czytaliśmy Wyprawe pierwsza, czyli pułapke grawitacyjna Stanisława Lema ze zbioru Cyberiada (1965) czy też znakomite w swojej prostocie opowiadanie Wierny stróż Sławomira Mrożka z tomu Deszcz (1962), to nieodzownym elementem naszych rozmów zawsze było przywoływanie postaci pisarza w stopniu, który pozwalał wyjść poza podręcznikowy, uproszczony schemat portretowania twórcy. Nie czynię zarzutu autorom narracji podręcznikowych, niemniej jednak w zależności od wieku, wiedzy uczniów, a także ich oczekiwań wobec mojej osoby starałem się oświetlać sylwetki poszczególnych pisarzy dyskretnie, by uczestnicy warsztatów mogli dostrzec $\mathrm{w}$ nich przede wszystkim ludzi, a nie fragment polskiej historii literatury. Oczywiście, zupełnie inaczej opowiadałem o Mikołaju Reju, a inaczej o Oldze Tokarczuk, choć unikałem typowej historycznoliterackiej narracji, opartej na pewnych schematach prezentowania biografii danego pisarza. Za każdym razem przedstawiałem pisarzy jako osoby, które nie tylko potrafiły wykorzystać swoje umiejętności artystyczne, ale także - czy przede wszystkim - systematycznie pracowały na swój sukces. Bardziej zatem interesowała mnie „przeciętność” czy „zwyczajność” życia pisarskiego - czego świadectwem były czytane na głos fragmenty ich utworów - niż ich „wyjątkowość” i „ponadprzeciętność”. Niekiedy wywoływałem 
tą postawą konfuzję wśród uczniów, przyzwyczajonych traktować literaturę z jednej strony jako zjawisko odległe od ich świata, a więc „nie-zwykłe”, „dorosłe”, z drugiej zaś, jako źródło nieskrywanej niechęci szczególnie wobec „panów tadeuszów”. Część nauczycieli, z którymi rozmawiałem przed i po warsztatach, wykorzystała fakt, że Olga Tokarczuk w roku 2019 zdobyła Literacką Nagrodę Nobla, i na przekór podstawie programowej - w której nie ma żadnej jej powieści czy opowiadania - kilka lekcji właśnie twórczości autorki Biegunów poświęciła. Tego typu wydarzenia, jak zdobycie przez Polkę lub Polaka Nagrody Nobla lub innego, prestiżowego na międzynarodowej arenie wyróżnienia - rzadkie i wyjątkowe w swoim charakterze - nie mogą być podstawą popularyzacji czytania literatury, ale z pewnością należy takie czy inne fakty w szkolnej edukacji wykorzystać, by budować pozytywną atmosferę wokół lektury jako kulturowego fenomenu.

2.

W ramach warsztatów wraz z uczniami zajmowaliśmy się fragmentami utworów polskiej i zagranicznej literatury, które zostały ułożone „parami” ze względu na obecny w nich temat. Wyboru dokonałem intuicyjnie, korzystając z ministerialnych wytycznych dotyczących lektur. Niemniej jednak sięgałem po pisarzy spoza szkolnego kanonu, jak Olga Tokarczuk, Mikołaj Rej i Andrzej Stasiuk. Między innymi przedmiotem ćwiczeń związanych z czytaniem ze zrozumieniem, interpretacją głosową oraz twórczym pisaniem były następujące teksty:

1. Pies: Henryk Sienkiewicz, $W$ pustyni i w puszczy (1911) - Sławomir Mrożek, Wierny stróż (1962),

2. Podróż: Stanisław Lem, Wyprawa pierwsza, czyli pułapka grawitacyjna (1965) - Andrzej Stasiuk, Jadac do Babadag (2004),

3. Podróż: Olga Tokarczuk, Podróż ludzi księgi (1993) - Rafał Kosik, Felix, Net i Nika oraz Teoretycznie Możliwa Katastrofa (2005),

4. Walka: John Ronald Reuel Tolkien, Hobbit, czyli tam i z powrotem (1937) - Rafał Kosik, Felix, Net i Nika oraz Gang Niewidzialnych Ludzi (2004),

5. Książka: Melchior Wańkowicz, Ziele na kraterze (1951) - Rafał Kosik, Felix, Net i Nika oraz Gang Niewidzialnych Ludzi (2004), Kapitulum XVII. Czytać poćciwemu, kto umie, jest rzecz bardzo potrzebna z Żywota człowieka poczciwego (1567/1568).

Warsztaty „Zabawy literackie. Piękne czytanie. Piękne pisanie” miały budowę trójdzielną, choć niekiedy od tej zasady odstępowałem, gdy któreś z ćwiczeń okazywało się zbyt skomplikowane dla uczniów i potrzebowali więcej, niż założyłem, czasu na jego wykonanie. Najczęstszym powodem było to, że niektórzy z uczestników w niewielkim stopniu angażowali się w pracę, albo też ćwiczenia wydawały im się po prostu nudne. Na marginesie warto odnotować fakt, że szkolna nuda ma co prawda niejedno oblicze, 
ale zawsze, według mnie, jest pochodną relacji uczeń - nauczyciel. To od stopnia zaangażowania pedagoga w codzienną pracę zależy, czy znudzona będzie większość, czy tylko nieliczni. Wizyty w szkołach województwa kujawsko-pomorskiego i prowadzenie warsztatów w różnych klasach tych samych placówek dostarczyło mi szeregu informacji o tym, w jaki sposób budować czy organizować lekcje polskiego, by nie stracić z oczu najważniejszego, a mianowicie motywacji młodych ludzi do czytania literatury i mówienia w sposób poprawny oraz efektywny. To zaś wymagało ode mnie modyfikowania ćwiczeń zasadniczych oraz współtowarzyszących, mających za zadanie wysondować umiejętności i wiedzę ucznia, ale także dostarczyć mi niezbędnych informacji o jego cechach charakterologiczno-osobowościowych.

Jako osoba dla wszystkich uczestników obca i należąca do innego niż szkolne środowiska zdawałem sobie doskonale sprawę z tego, że moje dydaktyczne doświadczenie wyniesione z przeszłości (szkoły podstawowa i liceum) oraz aktualne (uniwersytet) mimo oczywistych różnic czy odmienności zbiegają się w jednym punkcie. A mianowicie oparłem warsztat na aranżowaniu różnych form aktywności, choć nie zawsze przyzwyczajenia uczniów czy też „architektura” klasy pomagały mi w tym. Miałem zaledwie 90 minut na to, by przekonać uczestników warsztatów, że czytanie i rozmawianie o literaturze mogą być formą intelektualnej - choć nie tylko - zabawy. Za Johanem Huizingą (Huizinga 1964) i Rogerem Cailloisem (Caillois 1997) traktowałem to kulturowe zjawisko nie tyle jako pewien rodzaj rozrywki, ale mocno angażującą emocjonalnie i intelektualnie aktywność. Poza przestrzeganiem określonych zasad czy reguł jest niezmiernie ważne, by nadać zabawie (grze) odpowiednią dynamikę, która z kolei pozwoliłaby uczestnikom doświadczyć czegoś innego, niż przynosi im codzienność. Podobnie traktowałem prowadzone przez siebie warsztaty, choć mimo to starałem się budować pomosty między światem „zabaw literackich” a warunkami stwarzanymi przez szkolną edukację.

Pierwsza część „Zabaw literackich” najczęściej miała charakter sondujący poziom językowej i komunikacyjnej sprawności uczniów. Zarazem starałem się pobudzić ich intelektualnie i fizycznie, proponując ćwiczenia opierające się na: 1) myśleniu asocjacyjnym, którego punktem wyjścia były wypowiadane przeze mnie wyrazy, 2) zapisywaniu przez uczniów skojarzeń (tylko rzeczowników) na wcześniej przygotowanych kartkach, 3) umieszczaniu kartek z uczniowskimi wyrazami na rozwieszonej wzdłuż tablicy taśmie. Każdy z uczestników zapisywał na złożonej na pół kartce tylko dwa słowa, które kojarzyły się mu z wypowiadanymi przeze mnie. Starałem się je dobierać w taki sposób, by tworzyły antynomiczną parę, na przykład: kara - nagroda, ciemność - jasność, choroba - zdrowie, śmierć - życie. Na kolejnym etapie każdy z uczestników umieszczał zapisane przez siebie asocjacje na taśmie, by wszyscy mogli się z nimi zapoznać. 

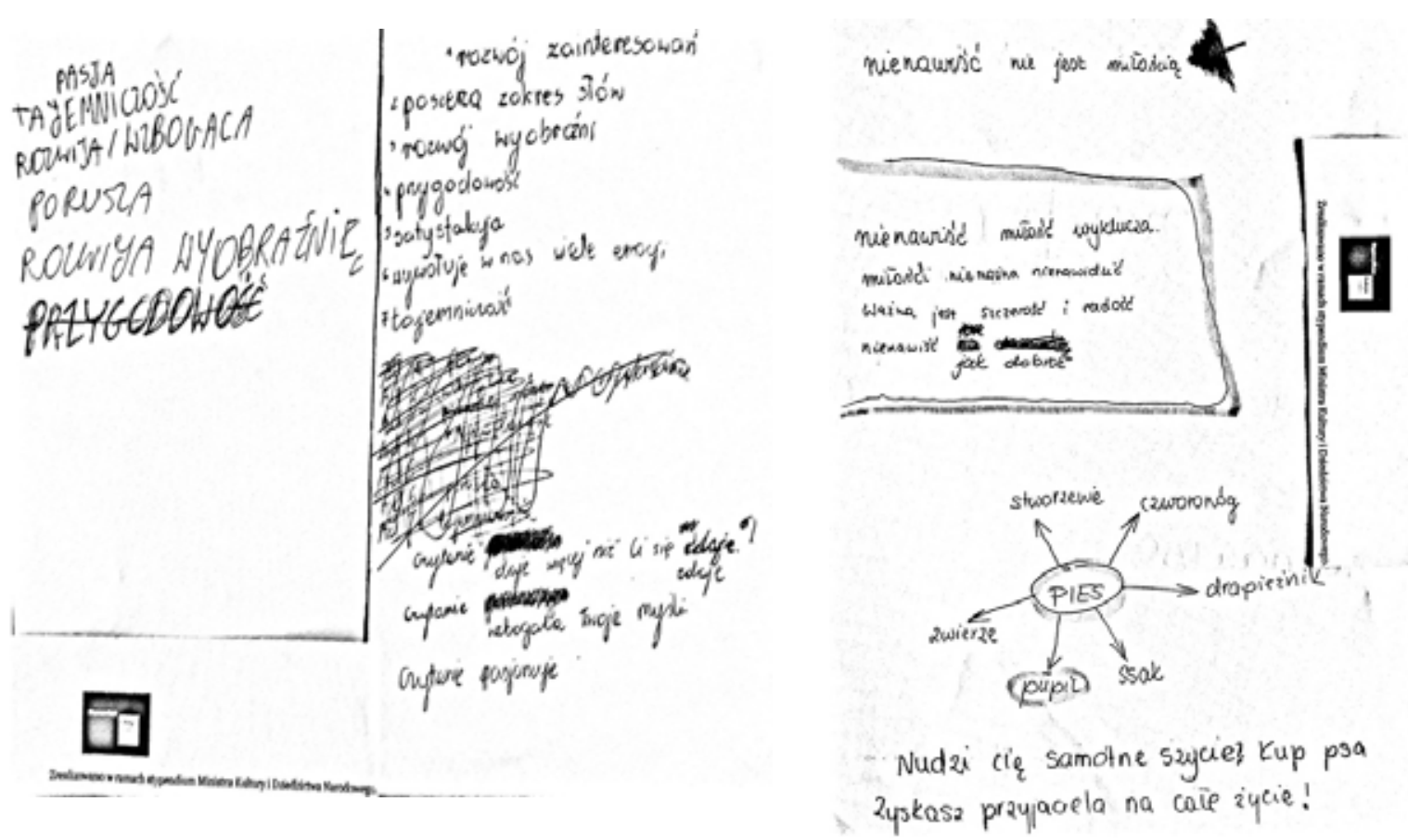

Uczniowskie „szkice asocjacyjne” do wyrazów: „pasja” i „pies”
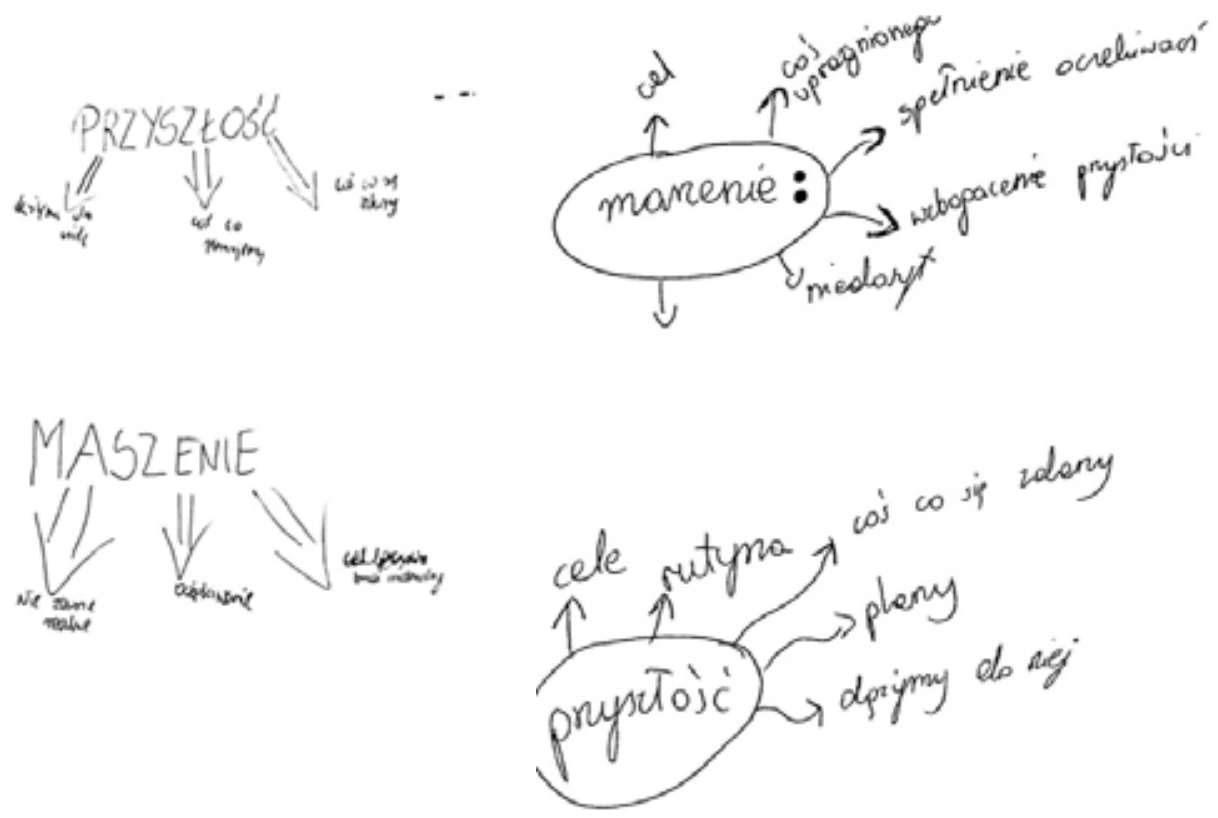

\section{回}

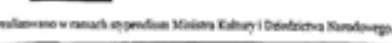

\section{田}

Uczniowskie „Szkice asocjacyjne” do wyrazów: „przyszłość” $i$ „marzenie” 

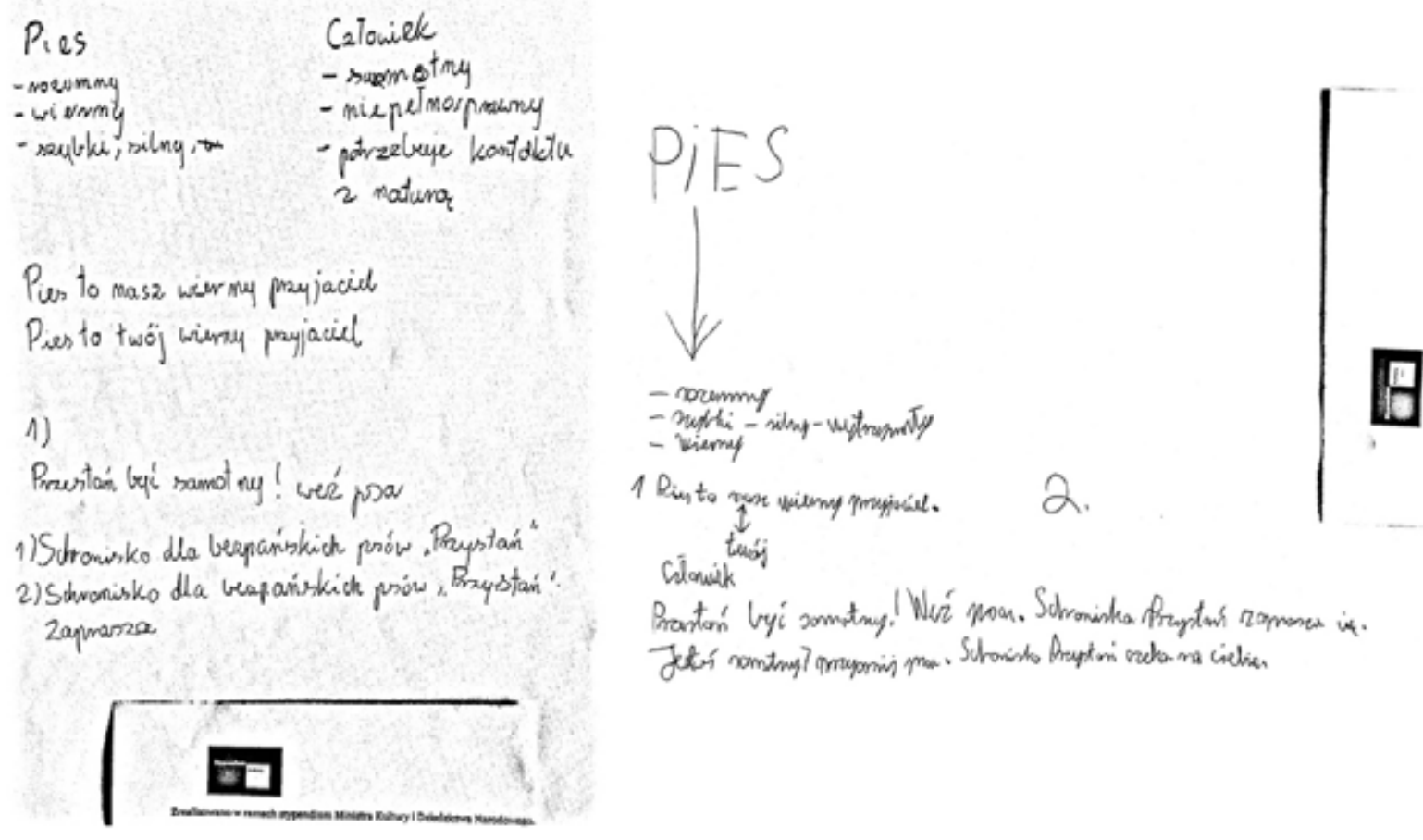

\section{Uczniowskie „szkice asocjacyjne” do wyrazu „pies”}

W zależności od atmosfery panującej na zajęciach proponowałem albo „dobre”, albo też „złe” wyrazy prezentować jako pierwsze. Po spontanicznych uczniowskich komentarzach odwracałem co drugą kartkę i w ten sposób „dobre” wyrazy przetykałem „złymi” lub na odwrót. Następnie przystępowaliśmy wspólnie do głośnych odczytań wyrazów w taki sposób, by za pomocą tonu i barwy głosu oddać ich pozytywne bądź negatywne znaczenie. Ćwiczenie powtarzaliśmy kilkukrotnie, gdyż uczniowie czasem gubili wcześniej ustalony rytm albo mieli problemy z prawidłową artykulacją. Kiedy wspólna interpretacja głosowa nabrała właściwej płynności, proponowałem zwiększenie tempa, co niekiedy wywoływało wśród uczniów rozbawienie. Na końcowym etapie pełniłem rolę dyrygenta, który gestami kontrolował sposób modulowania głosu, by wydobyć z „martwych” wyrazów żywioł komunikacyjny i swoistą melodię.

Część pierwsza warsztatów kończyła się zapisaniem wskazanych przez uczniów trzech „dobrych” i trzech „złych” wyrazów na tablicy tak, aby tworzyły strukturę mowy wiązanej. Następne zadanie polegało na „wypełnieniu" jej - czy dopełnieniu - wyrazami, które utworzą swego rodzaju wiersz. Z uczniami Szkoły Podstawowej nr 4 im. por. Zbigniewa Kruszelnickiego ps. „Wilk” w Grudziądzu wspólnie ułożyliśmy następujący tekst, którego strukturę wyznaczały wyrazy: „przyjaźń”, „nienawiść”, „wakacje”, „szkoła”, "gra” oraz „krzyczenie”:

przyjaźń nasza to nie jest nienawiść ale w wakacje kiedy nie ma szkoły gra toczy się między nami bez krzyczenia 
W Grudziądzu nie tyle chodziło mi o uzyskanie efektu estetycznego, ale raczej o pokazanie (lub przekonanie), że tekst literacki może być niemal pozbawiony środków stylistycznych. Zazwyczaj wyzwolona w trakcie artykulacyjnych ćwiczeń energia pozwalała mi poprowadzić uczniów w kierunku rzemiosła, a uniknąć pytań o sens pisania „wiersza”. W wypadku braku inwencji organizowałem wspólne „dokładanie treści”.

Druga część „Zabaw literackich” rozpoczynała się po kilkuminutowej przerwie, w czasie której archiwizowałem dokonania uczniów i rozdawałem przygotowane fragmenty utworów literackich wraz z czterema ćwiczeniami mającymi podobną postać. Na przykład, gdy przedmiotem działań warsztatowych były fragmenty utworów Lema (Wyprawa pierwsza, czyli pułapka grawitacyjna) i Stasiuka (Jadac do Babadag), uczniowie mieli do wykonania następujące zadania:

1. Przeczytaj uważnie fragmenty tekstów i ustal, co jest w nich głównym tematem, a następnie podkreśl związane z nim wyrazy.

2. Czym różni się tekst Stanisława Lema od tekstu napisanego przez Andrzeja Stasiuka? Zwróć uwagę na ich budowę oraz sposób przedstawienia w nich głównego tematu. Nadaj fragmentom własne tytuły.

3. Zastanów się nad tym, w jaki sposób należy przeczytać obydwa fragmenty, by za pomocą głosu oddać panujący w nich nastrój? Dokonaj głosowej interpretacji jednego z dwóch fragmentów.

4. Rozwiń w postaci tekstu fantastycznego lub realistycznego następujące zdania: „Wysoko, skrajem zrudziałych łąk, idzie stado krów. Zaraz znikną w lesie."

Z kolei w wypadku lektury fragmentów $W$ pustyni $i w$ puszczy Sienkiewicza oraz opowiadania Wierny stróż Mrożka zaproponowałem następujący zestaw ćwiczeń:

1. Przeczytaj uważnie fragmenty tekstów i ustal, co jest w nich głównym tematem, a następnie podkreśl związane z nim wyrazy.

2. Czym różni się tekst Henryka Sienkiewicza od tekstu napisanego przez Sławomira Mrożka? Zwróć uwagę na ich budowę oraz sposób przedstawiania $\mathrm{w}$ nich głównego tematu. Nadaj fragmentom własne tytuły.

3. Zastanów się nad tym, w jaki sposób należy przeczytać obydwa fragmenty, by za pomocą głosu oddać panujący w nich nastrój? Dokonaj głosowej interpretacji jednego $\mathrm{z}$ dwóch fragmentów.

4. Rozwiń w postaci tekstu fantastycznego następujące zdanie: „Rozczulają nas tylko małe pieski, kotki i pszczółki, słowem wszystko to, o czym wiemy, że w razie czego damy sobie z tym radę". W przywołanych dalej przykładowych pracach uczniowskich zachowuję oryginalną pisownię. 
Zabawy literackie w szkole podstawowej - czytanie, pisanie i interpretacja głosowa

Rozczulają nas tylko małe pieski, kotki i pszczółki, słowem wszystko to, o czym wiemy, że w razie czego damy sobie $\mathbf{z}$ tym radę. Miałem psa który wabił się Aga i był, jamnikiem. On bardzo lubił ryć w ogrodzie za domem i kiedyś przypadkowo odkopał jakąś tajemniczą rzecz. To był mały zamykany, na kluczyk kuferek. Aga szczeknoł i ja ze starszym bratem podszedłem. Aga nie chciał odejść i szczekał a chcieliśmy kuferek otworzyć. Zawołaliśmy na tatę. Tata odegnał Agę i kazał nam wziąść kuferek. W środku były skarby. (Uczeń VI klasy, Szkoła Podstawowa w Gronowie)

Rozczulają nas tylko małe pieski, kotki i pszczółki, słowem wszystko to, o czym wiemy, że $\mathbf{w}$ razie czego damy sobie $\mathbf{z}$ tym radę. Yon żył na Marsie razem ze zwierzęciem mniejszym od ziarnka piasku. Ale to był bardzo mądry i waleczny pyłkosz czyli odmiana pszczoły która dożywa nawet 2 milionów lat. Yon z pyłkoszem byli zaprzyjaźnieni od wielu lat i nagle musieli się rozstać. Yon musiał polecieć na inną planetę zupełnie sam. Przykazał pyłkoszowi żeby ten mógł zostać sam. Pyłkosz nie chciał się zgodzić. Yon jednak zamknął go w specjalnym pudełku, które nie przepuszczało, nawet takich małych zwierząt. (Uczennica klasy VII, Szkoła Podstawowa nr $13 \mathrm{w}$ Toruniu)

Biorąc pod uwagę pierwsze trzy punkty, moim głównym zamierzeniem było kształcenie umiejętności, po pierwsze, czytania ze zrozumieniem i, po drugie, interpretacji głosowej. Aby uczniowie mogli odpowiednio wykonać ćwiczenia, najpierw należało ustalić z nimi podstawowe informacje związane z budową tekstu, choć nie stanowiło to mojego głównego celu. Starałem się przede wszystkim kierować ich uwagę na związek między strukturą czytanego na głos utworu z jego - jakkolwiek by to nie zabrzmiało banalnie - formą i treścią. Niekiedy wspólnie czytaliśmy cały akapit, by uczniowie mogli uchwycić zawarty w nim sens, a niekiedy tylko pojedyncze wyrazy lub związki wyrazowe istotne dla wymowy utworu. Zabawa dźwiękiem wypowiadanego wyrazu lub ciągu zdań okazywała się dla większości uczniów doświadczeniem nowym, ale przyjemnym, pozwalającym spożytkować część drzemiącej w nich energii. Różne strategie czytania, a więc szybkie lub wolne (niemal zakłócające sens tekstu), głośne lub ciche, przechodzące w szept okazywało się dla młodych ludzi rodzajem relaksu, który burzył zwykłą, klasową codzienność, ale - według mnie - stanowiło to niezbędne przygotowanie do tego, by uczniowie mogli przystąpić do twórczego rozwinięcia zdania lub zdań w konwencji fantastycznej lub realistycznej. Różne formy indywidualnej i zbiorowej artykulacji dłuższych czy krótszych tekstów przynajmniej część uczestników aktywizowały fizycznie i intelektualnie, ale także niwelowały początkowe napięcie wywołane obecnością osoby obcej.

W ostatniej części warsztatów uczniowie przystępowali do pisania swojego tekstu, którego początek „przekazał” im ten lub innym pisarz lub pisarka. Poza wyjątkami większość uczestników zazwyczaj kończyła swoją pracę na kilku, kilkunastu zdaniach, będących ich twórczym rozwinięciem wskazanego przeze mnie fragmentu tekstu prozatorskiego. Zarchiwizowane uczniowskie efekty twórczego pisania cechuje przede wszystkim ubogie 
frazeologia i treść, co może być związane z tym, że mieli na wykonanie zadania zaledwie 20 minut. Podkreślałem jednak, że kreatywne rozwinięcie nie musi być obszerne i we wszystkich szczegółach dopracowane, ale powinno: 1) nosić wyraźne cechy konwencji fantastycznej bądź realistycznej, 2) treściowo i fabularnie zdecydowanie odbiegać od pierwowzoru, 3) zawierać przynajmniej jedną scenę z udziałem co najmniej jednego bohatera. Oto kilka wybranych przykładów z zachowaną oryginalną pisownią (drukiem pogrubionym zaznaczono zdania inicjalne):

Na początku podróży nie tyle ważny jest cel, co samo przesuwanie się w przestrzeni i czasie. Dowodem na to jest klasa 7, która jechała na wycieczkę do Wrocławia. W połowie drogi stało się coś niezwykłego, a mianowicie nagle kierowca autokaru zemdlał. Dzieci nie wiedząc o tym, dalej cieszyły się ich wspaniałą podróżą, aż w końcu wpadły do rowu. Wtedy dzieci zaczęły znikać jakby za pomocą magi. Było to dziwne, szczególnie dla wychowawcy tej klasy, który jako jedyny został w autokarze. Uczniowie nie odjechali daleko od szkoły, więc wychowawca postanowił pójść pieszo do szkoły. Gdy już doszedł uczniowie siedzieli i uczyli się Języka Polskiego. (Uczennica VII klasy, Szkoła Podstawowa im. S. Broniewskiego „Orszy” w Wałdowie Szlacheckim)

Na początku podróży nie tyle ważny jest cel, co samo przesuwanie się w przestrzeni i czasie. Taką odpowiedź dawał każdy, kto śmiał kwestionować sposób życia Santany. Dziewczyna od lat przemieszczała się z miejsca na miejsce w swoim starym zniszczonym wozie, nie mając pojęcia dokąd zmierza. Nie miała potrzeby zatrzymywania się gdziekolwiek, nikt nie był pewny gdzie w tej chwili przebywa.

Brunetka mogła wydawać się wychudzona, gdyż wszystkie pieniądze przeznaczyła na paliwo i dbanie o swój ukochany pojazd. (Uczennica VII klasy, Szkoła Podstawowa im. S. Broniewskiego „Orszy” w Wałdowie Szlacheckim)

Kserokopiarka odsunęła się od ściany, a jej cztery szuflady na papier wyskoczyły na ziemię i odbiegały w różnych kierunkach. Kserokopiarka zaczęła wariować wszystkie elementy rozbryzgiwały się w różne strony szuflady zaczęły tańczyć po całej przestrzeni, a z kawałków kserokopiarki powstał zespół muzyczny który grał muzykę rokową. Lodówka i mikrofala dołączyły się do tańca. Garnek z innej przestrzeni wleciał przez sufit rozwalając go i psując całą orkiestrę. (Uczeń klasy VI Szkoły Podstawowej nr 1 w Lubiczu Dolnym)

Kserokopiarka odsunęła się od ściany, a jej cztery szuflady na papier wyskoczyły na ziemię i odbiegały $\mathbf{w}$ różnych kierunkach, papier również uciekał. To rozśmieszyło osoby, które widziały to zdarzenie. Śmiali się, że zaraz ich plecaki, książki pouciekają. Jedna osoba była zaskoczona, myślała, że to duchy i zaczęła panikować. Wszyscy jednak uspokoili zaskoczoną osobę, że to tylko kserokopiarka się psuję. Jednak kserokopiarka zaczęła przesyłać jakieś niezrozumiałe wiadomości, wszyscy się zaniepokoili. Nagle zaczęła piszczeć, a wszyscy woleli pójść niż oglądać to zjawisko. Okazało się, że papier, szuflady zaczęły wracać radośnie podskakując i wszyscy powrócili na miejsce zebrania.

- No w końcu - ktoś powiedział z oddali.

- Tak, już się nie cierpliwiliśmy - powiedziało kilka osób. (Uczeń VI klasy, Szkoła Podstawowa im. S. Broniewskiego „Orszy” w Wałdowie Szlacheckim) 
Dwa pierwsze teksty $\mathrm{w}$ większym stopniu niż dwa kolejne spełniają wskazane przeze mnie wymogi i są fabularnie bardziej urozmaicone. Ale właśnie drugi wzór tworzenia tekstu był wśród uczestników wszystkich warsztatów dominujący. To znaczy w większości nie tylko nie potrafili rozwinąć swojej historii w taki sposób, by różniła się od pierwowzoru, lecz także mało twórczo wykorzystywali elementy (motywy, postacie, miejsca, przestrzenie), które zawarł w swoim utworze pisarz. Mimo wcześniejszych ćwiczeń towarzyszących i prób obudzenia w młodych ludziach kreatywności przeważały teksty odtwórcze, schematyczne, wykorzystujące pewne fabularne rozwiązania znane z gier komputerowych czy filmów (np. Avenger, Harry Potter, Transformers). Bezpośrednich odniesień do innych niż literatura przekazów jest w minitekstach uczniów wiele, niewiele zaś jest „zapożyczeń" z omawianych choćby w szkole utworów czy nawet komiksów.

Realizacja projektu w różnych szkołach województwa kujawsko-pomorskiego uzmysłowiła mi kilka faktów, które mogą - choć nie muszą - być przyczyną przeciętnego wyniku z testu ósmoklasisty. Po pierwsze, nauka języka polskiego w szkole podstawowej wymaga - ze względu na gwałtowne przemiany kulturowe i społeczne - dużej edukacyjnej wyobraźni od nauczyciela i jego intelektualnego zaangażowania, by skutecznie mobilizować wychowanków do pracy. Nie sprzyjają temu ani warunki - w tym finansowe - pracy w dzisiejszej szkole, ani niestabilność strukturalna szkolnictwa niższego w naszym kraju. Po drugie, ze względu na wciąż niepokojąco niski poziom czytelnictwa w Polsce należy w ramach lekcji polskiego robić wszystko, by rozpalać, a nie gasić ciekawość taką czy inną odmianą literatury. Według mnie rozbudzanie ciekawości światami literackimi należałoby uczynić jednym z głównych celów edukacji polonistycznej w szkole podstawowej. Po trzecie wreszcie, interpretacja głosowa oraz pisanie (także to twórcze, a więc zmuszające do kreatywności na poziomie stylu, tematu i kompozycji) powinny być stałym elementem większości lekcji polskiego.

\section{Bibliografia}

Caillois Roger, 1997, Gry i ludzie, Tatarkiewicz A., Żurowska M. (przeł.), Warszawa.

Huizinga Johan, 1964, Homo ludens: zabawa jako źródło kultury, Kurecka M., Wirpsza W. (przeł.), Warszawa.

Kłakówna Agnieszka, 2016, Akademicki Podręcznik myślenia o zawodzie szkolnego polonisty. Język polski. Wykłady z metodyki, Kraków.

Koc Krzysztof, 2011, Sztuka mówienia, słuchania, pisania, czytania, Kwiatkowska-Ratajczak M. (red.), Innowacje i metody. W kręgu teorii i praktyki. Podręcznik akademicki dydaktyki kształcenia polonistycznego, Poznań.

Korolko Mirosław, 1998, Sztuka retoryki. Przewodnik encyklopedyczny, wyd. 2., Warszawa. 
Myrdzik Barbara, 2020, O potrzebie ksztattowania autonomii poznawczej i egzystencjalnej na lekcjach nie tylko języka polskiego, „Polonistyka. Innowacje", nr 11.

Stan czytelnictwa w Polsce w 2019 roku. Wstępne wyniki, https://www.bn.org.pl/ download/document/1587585168.pdf (dostęp: 8.09.2019).

Wróblewski Maciej, 1998, Uwarunkowania kompozycyjne tekstu udanego, Porayski-Pomsta J., Podracki J. (red.). Tekst, wypowiedź, dyskurs $w$ dydaktyce szkolnej: materiały $z$ III z konferencji "Z badań nad kompetencja i świadomościa językowa dzieci i młodzieży”, Warszawa, 12-13 czerwca 1997 roku, Warszawa.

\section{O Autorze}

Maciej Wróblewski - literaturoznawca, adiunkt, kierownik Pracowni Badań Kultury i Literatury dla Dzieci i Młodzieży oraz Katedry Antropologii Literatury i Nowych Mediów na Wydziale Humanistycznym Uniwersytetu Mikołaja Kopernika w Toruniu. Publikował swoje artykuły w językach polskim i angielskim, m. in. w „Pamiętniku Literackim, „Przeglądzie Humanistycznym”, „Archiwum Emigracji”, „Ruchu Literackim”, „Polonistyce”, „Literaturze Ludowej”, „Childhood Remix Journal”, „Filoteknosie”. Jest pomysłodawcą i redaktorem naukowym serii „Biblioteczka Dziecięca”, w której do tej pory ukazały się 4 tomy poświęcone literaturze oraz sztuce dla dzieci i młodzieży. Dotychczas wydał 6 monografii: Proza niefikcjonalna $w$ edukacji polonistycznej ucznia szkoły średniej [1855-1939] (2003), Jan Rymarkiewicz - XIX-wieczny humanista (2006), Czytanie przyszłości. Polska fantastyka naukowa dla młodego czytelnika (2009), Człowiek $w$ przestrzeniach szkoły. Studium antropologiczne (2014), Literatura i maszyna (2015) oraz Doświadczanie dzieciństwa. Studium z antropologii literatury (2019). Od roku 2018 pełni obowiązki przewodniczącego jury Nagrody Literackiej im. Jerzego Żuławskiego. 